\title{
An annotated preliminary list of the Chironomidae (Diptera) of ZurQuí, Costa Rica
}

\author{
John H. Epler \\ 461 Tiger Hammock Road, Crawfordville, Florida, 32327, U.S.A. Email: johnepler3@,comcast.net
}

\begin{abstract}
An annotated list of the species of Chironomidae found at a four-hectare site, mostly cloud forest, in Costa Rica is presented. A total of 137 species, 98 of them undescribed, in 63 genera (17 apparently new), were found.
\end{abstract}

\section{Introduction}

The tropics have long been known as areas of great biodiversity (e.g. Erwin 1982), but our knowledge of many insect groups there remains poor. The two volume "Manual of Central American Diptera" (Brown et al. 2009, 2010) provided the first modern tools to analyze the diversity of one of the largest orders of insects, the Diptera (two-winged flies) of the northern portion of the Neotropics; Spies et al. (2009) covered the Chironomidae. These volumes offered the first family level identification keys for Central America (the first for any portion of the Neotropics) and also allow identification to the generic level of the described Central American Diptera. However, these volumes are just scratching the surface of Neotropical fly diversity. At both the genus and especially the species level, a tremendous amount of work remains to be done.

Art Borkent and Brian Brown conceived and developed a survey project for identifying all the Diptera species of a small area in Costa Rica. The study, patterned after an "All Taxa Biotic Inventory" (ATBI), but devoted entirely to the order Diptera, was called the Zurquí All Diptera Biodiversity Inventory (ZADBI). Fifty-nine collaborators took part in the project; I was fortunate to work with the Chironomidae. Borkent \& Brown (2015) provided an overview of the project and its protocol.

As will be seen below, a large number of undescribed genera and species were found, as well as many new records for Costa Rica. This paper is also meant to update the generic synopses provided by Spies et al. (2009).

\section{Material and methods}

The majority of material came from the main site at Zurquí de Moravia (hereafter Zurquí), located at $10.047313^{\circ} \mathrm{N}, 84.008457^{\circ} \mathrm{W}$, in San José Province, Costa Rica, collected from September 2012 to October 2013 . The 150 by $266 \mathrm{~m}$ site, at an elevation of $\sim 1600 \mathrm{~m}$, is mostly cloud forest, with adjacent small pastures; the site has one permanent and one temporary stream, located in heavily forested ravines.

Collecting methods included two malaise traps run continuously and additional traps run three days each month: three additional malaise traps, several emergence traps (over leaf litter; over dry branches; over vegetation; over stagnant water; over running water), CDC light traps, bucket light traps, yellow pan traps, flight intercept traps and mercury vapor light traps. Some specimens were collected by sweeping and by hand.

Samples were sorted and prepared by technicians at the Instituto Nacional de Biodiversidad (INBio). Given the difficulties of female identification, for the most part only males were removed from the samples for identification. Thus parthenogenetic species, such as Phytotelmatocladius delarosai Epler, known from the USA (Florida) to Argentina (Epler 2010, Siri \& Donato 2014) may have been missed.

\section{Results}

A total of 2,120 specimens were examined. Four subfamilies, 63 genera and 137 species were represented (Appendix 1). The majority of species (98), and 17 new genera, are apparently undescribed and were given letter/number designators. It is anticipated that a great deal of time will be necessary to describe all these new taxa. Workers whose work may involve some of these taxa are welcome to contact me with ideas for producing descriptions. Funding sources are also being sought.

All but one of the putatively new genera were orthoclads and are listed as "CHIRORTH-n", referring to "Chironomidae: Orthocladiinae" followed by a number; e.g., "CHIRORTH-1 sp. ZUR-1". The single CHIRCHIR-1 is a damaged specimen of a Chironominae, and may represent a known genus, but its combination of available characters does not allow generic placement. Undescribed species are listed with "ZUR-n", referring to new taxa from the Zurquí project (I also have numerous other undescribed species from Costa Rica, 
collected over the past several decades, that have been given different letter/number designators; with the possible exception of a single species of Parametriocnemus, none of these other undescribed taxa were found in the Zurquí material). A list of the taxa collected is presented in Appendix 1. An annotated accounting of these taxa follows below; any mention of morphological characters is not to be taken as a description of a taxon. Note also that the relative numbers or percentages given for species collected are not representative of the total catch, and pertain just to the material that was selected to be mounted.

\section{PODONOMINAE}

Parochlus - A single taxon belonging to the $\mathrm{Pa}$ rochlus araucanus group (Brundin 1966) was collected. Because pupae are necessary for species delimitation in this group, species-level identification of this taxon will have to wait until pupae are collected and associated.

\section{TANYPODINAE}

Procladius - To date, only one species of the subgenus $P$. (Procladius) has been reported from the Neotropics: P. mozambique Roback, from Colombia (Roback 1982b). The single species of Procladius collected at Zurquí, P. (Procladius) sp. ZUR1, more closely resembles $P$. (P.) paludicola Skuse, an Australian species (Roback 1982a), but differs in coloration and morphology.

Thienemannimyia - Thienemannimyia (Thienemannimyia) sp. ZUR-1 may be the species referred to by Watson \& Heyn (1993) as Thienemannimyia nr barberi (Coq). It resembles T. barberi (Coquillett), a western US species, but the wing pattern appears slightly different; comparison of more Costa Rican and Nearctic material is necessary.

Zavrelimyia - Zavrelimyia (Paramerina) fasciata, as Paramerina fasciata Sublette \& Sasa, was described from Guatemala (Sublette \& Sasa 1994); it is widespread in Costa Rica and was the most common tanypod collected in the study.

\section{ORTHOCLADIINAE}

Antillocladius - Three species were collected; $A$. pluspilalus was the most common (59 specimens). The genus has most recently been reviewed by Mendes \& Andersen (2008) and Mendes et al. (2011).

Bryophaenocladius - Of the five Bryophaenocladius species collected, four are undescribed. The fifth species is listed here as B. cf. psilacrus. Bryophaenocladius psilacrus was described from South Carolina, USA, by Sæther (1982), based on a single specimen. A key character for this species was the absence of acrostichal setae. The Zurquí material (41 specimens) all had some acrostichal setae; otherwise the specimens appear to be $B$. psilacrus. The type was not available for examination.

Although a widespread and speciose genus, few Bryophaenocladius species are known from the Neotropics. Wang et al. (2006) and Donato (2011) provided the most recent treatments of the genus for the area. It is possible that some of the taxa that I've grouped here may belong elsewhere.

Compterosmittia - Three species were collected; the most common (104 specimens) was the undescribed $C$. sp. ZUR-1, followed by C. nerius (43 specimens). A single specimen of $C$. sp. ZUR-2 was collected. The genus was most recently reviewed, for taxa from the area, by Mendes et al. (2004).

Corynoneura - Two undescribed species were collected in addition to two described species: $C$. ferelobata was described from Guatemala by Sublette \& Sasa (1994); C. guanacaste was described from northern Costa Rica by Wiedenbrug et al. (2012).

Cricotopus - About 15 species are recorded or described from the Central American-Caribbean area (Spies \& Reiss 1996). All eight of the Cricotopus species that were collected at Zurquí appear to be undescribed; all belong with the subgenus $C$. (Cricotopus).

Diplosmittia - Two undescribed species were collected, in addition to $D$. forficata, described from La Selva, Costa Rica, by Andersen (1996). The genus has recently been reviewed by Pinho et al. (2009) and Wiedenbrug \& Silva (2016) added an additional species from the Dominican Republic. The single specimen of $D$. sp. ZUR-1 lacks antennae and bears a well developed inferior volsella; it may belong elsewhere but is placed in Diplosmittia until more complete material can be collected. Diplosmittia sp. ZUR-2 resembles D. beluina Andersen (described from La Selva, Costa Rica) but has 13 antennal flagellomeres, with an AR of 3.0-3.4, and a more sharply pointed anal point; $D$. beluina has 10 flagellomeres and an AR of 0.62. Both taxa have a long costal extension. The two taxa may be conspecific but more material is necessary to determine antennal vaiability.

Eukiefferiella - Three undescribed species that fit Eukiefferiella were collected. No described species are known from the Neotropics; Watson \& Heyn (1993) recorded larvae from Costa Rica. 
Gravatamberus - The genus was established by Mendes \& Andersen (2008); they included five species found in Brazil, Chile, Costa Rica, Guatemala, Mexico and Venezuela. Gravatamberus curtus Mendes \& Andersen was described from material (three specimens) from Mexico and northwestern Costa Rica; G. guatemaltecus was described from a single specimen from Guatemala. The two species were diagnosed by the number of setae in cell $\mathrm{m}$ proximal to RM, number of setae on the subcosta, the length of the costal extension and the AR: G. curtus has $<10$ setae in cell $\mathrm{m}$ proximal to RM ( $G$. guatemaltecus $>10)$; subcosta with 6-15 setae ( $G$. guatemaltecus 16$)$, costal extension 68-86 $\mu \mathrm{m}$ ( $G$. guatemaltecus 161); AR 0.64-0.69 (G. guatemaltecus 0.26).

Eighteen males of Gravatamberus were collected; unfortunately, antennae were missing on all of them. All had a costal extension, ranging from 128 to $200 \mu \mathrm{m}$ (Table 1), greater than that recorded for $G$. curtus. However, the range of setae in cell $\mathrm{m}$ proximal to RM ranged from 0 to 24 in the Zurqui material, regardless of costal extension length, suggesting that this character does not aid in distinguishing G. curtus from G. guatemaltecus. All Gravatamberus collected in this study are considered to represent G. guatemaltecus.

Data also indicate that the midges had more setae in cell $\mathrm{m}$ and on the subcosta from February to
May, with fewer setae present in those wing areas from May (one specimen) through October.

Irisobrillia - Eight specimens of the sole species of the genus, I. longistyla, were collected.

Krenosmittia - Two specimens were collected of a species that appears to belong with Krenosmittia. This would be the first record for the genus from the Neotropics. Examination of more material is necessary.

Limnophyes - Limnophyes was one of the more common of the small orthoclad taxa collected ( $\sim 8 \%$ of total mounted catch). Two species were collected: L. mariae (38 specimens) and the much more common L. guatemalensis (142 specimens), both described from Guatemala by Sublette \& Sasa (1994).

Lipurometriocnemus - Four species were collected, three of them undescribed. Lipurometriocnemus was first described from the British West Indies by Sæther (1981), with L. glabalus as the sole species. Sæther (1982) then described L. vixlobatus from South Carolina, USA. The two species were supposedly separated by the absence of setae on $\mathrm{R}_{1}$, a weak inferior volsella and a "slight hump on tergite IX representing a reduced anal point" in L. vixlobatus. Cranston \& Oliver (1988) reported L. vixlobatus from the Yukon Territory of Canada, and examined paratypes of L. glabalus and a sin-

Table 1. Selected measurements of Gravatamberus guatemalticus

\begin{tabular}{lllll}
\hline Specimen \# & Month collected & cell m setae & subcosta setae & costal extension, $\mu \mathrm{m}$ \\
\hline 4399193 & OCT & 0 & 5 & 175 \\
4401710 & JUN-JUL & 1 & 4 & 195 \\
4401650 & JUN-JUL & 0 & 6 & 200 \\
4401625 & OCT & 0 & 5 & 155 \\
4400249 & JUN & 1 & 5 & 180 \\
4405861 & MAY & 1 & 5 & 153 \\
4401624 & OCT & 0 & 9 & 200 \\
4400246 & JUN & 1 & 7 & 188 \\
4399225 & JUN & 0 & 5 & 155 \\
4399224 & JUN & 9 & 5 & 175 \\
4406521 & APR & 18 & 12 & 163 \\
4370228 & MAY & 17 & 17 & 153 \\
4363952 & APR & 24 & 14 & 128 \\
4363944 & FEB & 11 & 7 & 188 \\
4363957 & APR & 19 & 11 & 133 \\
4399449 & MAY & 15 & 10 & 165 \\
4406482 & APR & 13 & 6 & 150 \\
4406453 & MAY & 16 & 10 & 138 \\
\hline
\end{tabular}


gle specimen (which they thought to also represent L. glabalus) from Braulio Carillo National Park in Costa Rica (the Zurquí site is adjacent to a portion of the huge park). They noted that the two species were difficult to separate because of variation in the supposedly diagnostic characters, but gave no reason why they assigned the Yukon specimen to vixlobatus, which following its description should lack any setae on $\mathrm{R}_{1}$, instead of assigning it to $L$. glabalus. I noted such variation in the volsellae and "anal hump" in the Zurquí material I've designated as L. glabalus; there was variation in the length/ breadth of the gonostylus but much appeared due to the viewing angle. I saw no specimens in which $\mathrm{R}_{1}$ was devoid of setae and considered all material I put in this group to be L. glabalus (63 specimens).

My L. sp. ZUR-1(eight specimens) has genitalia similar to those of L. glabalus but has a very low AR ( 0.32-0.58) compared to what is being called L. glabalus today (following Cranston \& Oliver 1988 and Andersen et al. 2016). In Sæther's (1981) original description of L. glabalus, all of the type material lacked antennae, but it is now apparently assumed that the species has an AR similar to that of L. vixlobatus - around 1.60-1.75. Zurquí material of L. glabalus had ARs $>1.70$.

My L. sp. ZUR-2 (36 specimens) has an AR around 1.76-1.85 and genitalia very similar to those of $L$. glabalus, except the proximal portion of the gonostylus bears a hump that separates it from that of L. glabalus. Further work (i.e., measurements of other body parts, etc.) may show this taxon may also belong with L. glabalus.

My L. sp. ZUR-3 (two specimens) has an AR of about 1.0 or less and has a distinctively pronounced inferior volsella. Andersen et al. (2016) described two new Lipurometriocnemus species from Brazil and provided a key for the known species. Their $L$. biancae has a pronounced inferior volsella, but not the same as $L$. sp. ZUR-3, and an AR of 1.29-1.45. Their L. amazonicus (AR 1.23-1.45) is very similar to L. glabalus, but has fewer dorsocentral setae.

Litocladius - A single species (34 specimens), L. chavarriai, was collected.

Lopescladius - Two undescribed species, both belonging with the subgenus $L$. (Cordiella), were collected (seven of $L$. sp. ZUR-1; two of $L$. sp. ZUR-2).

Mesosmittia - The widespread M. patrihortae (22 specimens) and one undescribed species (one specimen) were collected. The genus was most recently reviewed by Andersen \& Mendes (2002). They noted that M. truncata Sæther, described from a single male specimen from Panama (Sæther 1985), was separable from $M$. patrihortae only by the length of the costal extension (116 $\mu \mathrm{m}$ in M. truncata; 8-62 $\mu \mathrm{m}$ in M. patrihortae). Costal extensions in Zurquí material ran from 50 to 140 $\mu \mathrm{m}$, indicating a wide range of lengths that would include the single measurement from the Panama specimen. I consider $M$. truncata to be a junior synonym of $M$. patrihortae.

Metriocnemus - Three species, two undescribed, were collected. The named species, Metriocnemus costatus, was described from Guatemala by Sublette \& Sasa (1994). Their description stated "genitalia with a midventral notched, somewhat quadrangular plate". One of the Metriocnemus species collected, initially designated $M$. sp. ZUR-2, was very similar to the description and illustrations for M. costatus (Sublette \& Sasa 1994: fig. 88) except it apparently lacked this plate. I was able to examine 6 paratypes of $M$. costatus from the Sublette Collection, located at the University of Minnesota, St. Paul, MN. The specimens were all excessively squashed (typical of Sasa mounts) and the quadrangular plate was apparent. I then remounted the abdomen/genitalia of one of the Zurquí $M$. sp. ZUR-2 specimens and excessively squashed it the quadrangular plate appeared! This plate is normally oriented in a dorsal-ventral manner and is visible as a thin sclerotized line when viewed in a typical genitalia mount that has not been excessively flattened. The structure may represent the aedeagus or an ejaculator (see Tuxen 1970: fig. 160).

Nanocladius - Eight specimens of a single undescribed species of Nanocladius (Nanocladius) were collected. The genus is poorly known from the Neotropics, with only three species described from the region to date (Epler 1986; Wiedenbrug \& Silva (2013).

Onconeura - One undescribed species (six specimens) of Onconeura was collected. This would be the second species known from Costa Rica; Spies \& Reiss 1996) recorded O. semifimbriata (Sæther) from the country. The most recent papers on $\mathrm{On}$ coneura are Donato et al. (2012) and Wiedenbrug et al. (2009).

Parakiefferiella - The genus is unrecorded from Central America; Wiedenbrug \& Andersen (2002) described several new species from South America and provided a review of the genus. Two specimens of an undescribed species were collected.

Parametriocnemus - Four species were collected; all appear to be undescribed. Parametriocnemus sp. ZUR-1 and $P$. sp. ZUR-2 resemble the Nearc- 
tic $P$. lundbeckii (Johannsen) but have a lower AR; $P$. sp. ZUR-1 was $0.67-0.72$; $P$. sp. ZUR-2 was 0.52-0.68 (for P. lundbeckii see below). Both may represent a single species; more measurements of other body parts are necessary.

Sublette (1967: 539) gave an AR of 1.40 based on a specimen (a "metatype") from the type series; he also gave ARs of four Johannsen-determined specimens that ranged from 1.26-1.60, mean 1.36. Sæther (1969) gave a range of 0.90-1.30, mean 1.12, for the AR of P. lundbeckii.

Sublette \& Sasa (1994) recorded larval, pupal and adult $P$. lundbeckii from Guatemala. I examined 4 females and one female pupal exuviae from this Guatemalan material (no males were available). None of these specimens could be reliably identified as $P$. lundbeckii.

Epler (2001: 7.117) discussed a Parametriocnemus from Great Smoky National Park that had genitalia similar to $P$. lundbeckii but had an AR of 0.40 . Two other specimens resembling $P$. lundbeckii from the same area have an AR of around 0.84, and I've also examined $P$. lundbeckii from the same area with "typical" ARs $(\sim 1.40)$. It appears obvious that a thorough study of $P$. lundbeckii is necessary to determine just what that species is.

According to my notes, $P$. sp. ZUR-4 resembles a species I have seen from northwestern Costa Rica that I had designated $P$. sp. CR-3. Those specimens, and other Costa Rican Parametriocnemus species, are out on loan and were not available for comparison. All of the Zurquí Parametriocnemus specimens had an AR below 1.00.

Paraphaenocladius - Paraphaenocladius exagitans longipes was one of the most common orthoclads collected, with 113 specimens examined. The subspecies was described from Costa Rica (type locality, Cacao (a volcano) in Guanacaste Province), St. Vincent and Trinidad (Sæther \& Wang 1995).

Pseudorthocladius - Two specimens of an apparently undescribed species were collected. Until this collection, Pseudorthocladius was not recorded from the Neotropical Region. The Zurquí species appears similar to $P$. clavatosus Sæther \& Sublette, but has a smaller inferior volsella. Pseudorthocladius clavatosus was described from two males and a female from South Carolina, U.S.A. (Sæther \& Sublette 1983); comparison with type material will be necessary to determine if the Zurquí specimens represent a new species.

Pseudosmittia - Three species were collected, one undescribed. Pseudosmittia windwardensis was the most common (75 mounted specimens), while 39 specimens of the widespread $P$. forcipata were collected. It should be noted that, pending further investigation, some of the putative new orthoclad genera found during this study may belong with Pseudosmittia. Ferrington \& Sæther (2011) provided the most recent review of the genus.

Stictocladius - One specimen of an undescribed species was collected. In the Western Hemisphere, this genus has been mostly recorded from Argentina, Chile and Peru, but has recently been found in North America (Sæther \& Cranston 2012). This would be the first record of the genus from Central America. The new Costa Rican species has clear wings and a very low AR of 0.21 .

Synorthocladius - Two specimens of an undescribed species were collected. Watson \& Heyn (1993) recorded "Synorthocladius sp." from Costa Rica.

The following orthoclad taxa appear to represent undescribed genera. These taxa are discussed below with mention of morphological characters in order to inform other workers that may have similar taxa and may wish to collaborate or borrow material. Please note again that any mention of morphological characters is not to be taken as a description of a taxon.

CHIRORTH-1 - A small species, represented by one specimen with bare eyes; 11 antennomeres; minute scalpellate (?) acrostichals; wing with strong punctation and bare squama; small rounded anal point; and each tarsal claw with 3 teeth.

CHIRORTH-2 - A small species with bare eyes; 13 antennomeres with low (0.43) AR; elongate thorax with a few decumbent acrostichals; 0-1 squamal setae, with long costal extension; abdomen with weak bands; no virga, no anal point.

CHIRORTH-3 - A small species with pubescent eyes; low AR (0.50); well developed scale-like virga; and a short, rounded anal point. Fifteen specimens were collected.

CHIRORTH-4 - There appear to be two species in this putative new genus, which differ from each other by having a radically different virga. The head has a U-shaped frons as in Jururumberus Mendes \& Andersen (Mendes \& Andersen 2013). This small-bodied genus also has bare eyes; $8 / 9$ antennomeres; no squamal setae; R ends just before $\mathrm{fCu}$ and no anal point. Numerous specimens were collected.

CHIRORTH-5 - A genus similar to Pseudosmittia, represented by four specimens. It features 
antennae with 13 flagellomeres; low AR (0.55); weak decumbent acrostichals; one squamal seta; wing veins without setae except near base of R; long costal extension; no pulvilli and deeply bifid tarsal claws.

CHIRORTH-6 - This taxon, represented by four specimens, resembles Saetheriella Halvorsen, in having reniform, protruding hairy eyes and a rounded to triangular anal point. However, it has an extended costa; well developed pulvilli; a well developed, clear, scutal tubercle; lacks a virga; and has superior and inferior volsellae.

CHIRORTH-7 - This genus has pubescent eyes; no observable acrostichal or squamal setae; a very long costal extension; a scale-like virga; and a short rounded anal point. Three specimens were collected.

CHIRORTH-8 - A single specimen of this taxon was collected. It has eyes with very short pubescence; antennae with 13 flagellomeres and very low AR (0.19); no apparent acrostichals; no squamals, no pulvilli; apically bifid claws; no volsella and a gonostylus that is widened preapically.

CHIRORTH-9 - Represented by two specimens, this genus has pubescent eyes, with pseudo-ocelli present; a grossly enlarged globose palpomere 3; numerous scalpellate acrostichals; a small patch of short setae lateral to and above the apex of the antepronotal lobes; no squamals; a long costal extension; very recurved $\mathrm{Cu} 1$ and a Mesosmittia-like anal point.

CHIRORTH-10 - A single specimen of this moderately large midge was collected. It has 13 flagellomeres; bare eyes; reduced $4^{\text {th }}$ and $5^{\text {th }}$ palpomeres; about 20 scalpellate acrostichals that originate at about $1 / 3$ the length of the scutum; finely punctate wing membrane; no squamals; sinuate $\mathrm{Cu}$; no anal point but a Mesosmittia-like median hump; abdominal tergites with dark posterior bands; and a well developed inferior volsella with a median swelling posterior and ventral to it.

CHIRORTH-11 - Two specimens were collected; both have lost their antennae. Eyes are bare; the acrostichals are absent or very minute; a weak virga is present; there are no volsellae present; and the gonostylus lacks a megaseta.

CHIRORTH-12 - A single specimen that lost its antennae was collected. It has hairy eyes; four palpomeres; no squamal setae; apparently no acrostichals; a virga; Mesosmittia-like anal point; and a small inferior volsella.

CHIRORTH-13 - This taxon has bare eyes; one palpomere; apparently no acrostichals; bare squama; elongate virga; and broadly spatulate anal point. Three specimens were collected.

CHIRORTH-14 - One specimen of this taxon was collected. It has bare eyes; 13 flagellomeres, with low AR (0.28) and a large seta on the last antennomere; no acrostichals; no squamals; a moderately long bare anal point and a well developed inferior volsella.

CHIRORTH-15 - A series of 10 specimens represents this genus, which has bare eyes; short palpomeres; two acrostichals at mid-scutum; long pulvilli; and no anal point. All specimens have lost their antennae.

CHIRORTH-16 - A single specimen of this midge was collected. It somewhat resembles Pseudosmittia, but has hairy eyes; no acrostichal or squamal setae; a long costal extension; weak virga; small inferior volsellae; arcuate gonostyli; and a short triangular/conical anal point lacking any large setae.

\section{CHIRONOMINAE}

Beardius - Two species were collected; B. triangulatus was described from Costa Rica by Andersen $\&$ Sæther (1996). One specimen of an undescribed species was collected. The genus was recently revised by Pinho et al. (2013).

Caladomyia - Two undescribed species were collected; one specimen of one species, two of the other. The genus was recently reviewed by Trivinho-Strixino (2012).

Cryptochironomus - Four specimens of an undescribed Cryptochironomus were collected.

Dicrotendipes - Fourteen specimens of an undescribed Dicrotendipes were collected. The species possesses an apically bifid inferior volsella. Although such a volsella is known from Afrotropical and Palaearctic species, as well as several Amazonian species (Epler 1988), this is the farthest north I have seen such a species in the Western Hemisphere.

Einfeldia - Five specimens of an undescribed Einfeldia were collected. The taxonomy of Einfeldia has been confused, with some species being allocated to other genera (Epler et al. 2013; Cranston et al. 2016). I examined the holotype of E. atitlanensis Sublette \& Sasa, described from Guatemala (Sublette \& Sasa 1994); this new species differs having a larger digitus of the superior volsella, a thinner gonostylus and darkened apices of the leg segments. 
Endotribelos - Two described species and one undescribed species were collected. Fourteen specimens of E. albatum and 40 (including two intersex specimens) of E. grodhausi were examined; seven specimens of the undescribed species were collected. The undescribed species has a long thin anal point and appears similar to, but lighter than, an undescribed species from La Selva, of which I have several reared associations.

Endotribelos was established by Grodhaus (1987) for Tendipes (Tribelos) hesperia Sublette, 1960 (which thus became Endotribelos hesperium (Sublette)), a southern US species whose larva has an odd number of teeth on the mentum and a large gap (diastema) between the molar area and the proximal inner tooth of the mandible. Subsequently, Sublette \& Sasa (1994) described two species from Guatemala, E. albatum and E. grodhausi; the larva of $E$. grodhausi has an even number of mental teeth and lacks the mandibular diastema (the larva of E. albatum remains unknown). Since then, several more species have been described from South America (Roque \& Trivinho-Strixino 2008 and Trivinho-Strixino \& Pepenelli 2015), the larvae of which display a variety of those character states. See also Epler et al. (2013).

Trivinho-Strixino \& Pepenelli (2015) provided keys for the males and known larvae of Endotribelos. However, male E. grodhausi will not key correctly because couplet 4 gives one the choice of "base of superior volsella setose" or "base of superior volsella bare". Choosing "bare" eventually leads to E. grodhausi at couplet 14 . However, the base of the superior volsella of E. grodhausi is clothed, ventrally and dorsally, with fine setae. Thus, E. grodhausi will key to E. jaragua Trivinho-Strixino \& Pepenelli in couplet 5, from which it may be separated by the darker thorax of E. grodhausi (preepisternum and adjacent sclerites are dark; light in E. jaragua). Sasa and Sublette's illustration of the volsella (Sublette \& Sasa 1994: fig. 141) does not indicate the presence of setae, which apparently led Trivinho-Strixino \& Pepenelli (2015) to assume the structure was bare. Sublette \& Sasa (1994: fig. 135) likewise illustrated the base of the superior volsella of E. albatum as bare, when it also is clothed with fine setae. I examined two paratypes of E. albatum and eight paratypes of E. grodhausi.

Nandeva - Two specimens of $N$. latiloba were collected; the species was described from Brazil by Sæther and Roque (2004). This is the first record of the genus from Costa Rica. Andersen et al. (2011) also recorded the species from Venezuela and confirmed the genus's position within the tribe Tanytarsini.

Nilothauma - Two undescribed species were collected. The genus was most recently reviewed by Mendes \& Andersen (2009).

Parachironomus - Four specimens of an undescribed Parachironomus were collected. The Neotropical Parachironomus were documented by Spies et al. (1994).

Phaenopsectra - A single specimen of an undescribed Phaenopsectra was collected.

Polypedilum - A very speciose genus world-wide, Polypedilum was the most abundant chironomine genus collected in the study, with one undescribed species of $P$. (Pentapedilum), one described and three undescribed $P$. (Polypedilum), three described and one undescribed $P$. (Tripodura) and one undescribed species of $P$. (Uresipedilum).

The undescribed P. (Pentapedilum) species was the most abundant Polypedilum collected, with 88 specimens mounted. Mendes, Andersen \& Jocqué (2011) described P. (Polypedilum) panacu from bromeliad phytotelmata in Honduras. Of the three described $P$. (Tripodura) collected, two were described by Sublette \& Sasa (1994) from Guatemala. One of these, $P$. (Tripodura) luteopedis was the second most abundant Polypedilum collected, with 75 specimens mounted; the widespread $P$. (T.) apicatum was described from New Mexico, U.S.A., by Townes (1945) and was also recorded from Guatemala by Sublette \& Sasa (1994).

Rheotanytarsus - One undescribed species, two described species and two tentatively identified described species were collected. Rheotanytarsus guancastensis, R. scutulatus and R. subtilis were described from northwestern Costa Rica by Kyerematen \& Andersen (2002); R. contrerasi was described from Mexico by Andersen \& Sæther in Kyerematen et al. (2000). Our specimens of $R$. $c f$. contrerasi and $R$. cf. guanacastensis differ slightly from their original descriptions and must be compared with type material for more positive identification.

Riethia - Fifteen male specimens of a genus from the putative tribe Pseudochironomini were collected; this genus is almost certainly Riethia, but there is a small chance they could be Manoa. Males of the two genera cannot at this time be separated utilizing morphological characters; only females and pupae may be separated at the generic level (Jacobsen \& Perry 2002; Trivinho-Strixino et al. 2009). I'm calling the Zurquí specimens Riethia based on their close resemblance to $R$. truncato- 
caudata (Edwards) as redescribed in TrivinhoStrixino et al. (2009) and R. manauara Neubern, Trivinho-Strixino \& Silva (Neubern et al. 2011); the medial apices of the inferior volsellae of all three species have large, flattened, apically pectinate setae directed mediad (and dorsad in R. truncatocaudata). Such setae are unknown in Manoa. Note that the legs of the Zurquí specimens are unbanded and there are other differences, especially in the superior volsella; thus, they do not represent $R$. truncatocaudata. Likewise, differences in the genitalia indicate that $R$. sp. ZUR-1 is not conspecific with $R$. manauara.

Stempellinella - Four specimens of one undescribed species were collected. The genus was recently review by Ekrem (2007).

Stenochironomus - Ten species of Stenochironomus were collected, only one of which was positively identified as a previously described species: S. nudipupa is known from Brazil, Costa Rica, Ecuador and Venezuela (Borkent 1984; Reis et al. 2013). A single specimen of $S$. cf. varius appears to be $S$. varius but lacks any coloration on its fore femur; it does have a darkened fore coxa and trochanter, and may represent a slight color variation of the species. Since Borkent's (1984) excellent revision of Stenochironomus and its allies, numerous additional species have been described from the Neotropics; Dantas et al. (2016) provided the most recent key for Neotropical Stenochironomus. Stenochironomus sp. ZUR-1 (six specimens) is similar to $S$. impendens Borkent, but has a different abdominal color pattern; $S$. sp. ZUR-2 (one specimen) has a dark, broad anal point, but has different thoracic and abdominal color patterns from any described species; S. sp. ZUR-3 (16 specimens) will key to $S$. sebastiao Andersen et al. (Andersen et al. 2008) in Dantas et al. (2016) but has a shorter, thicker superior volsella and other hypopygial differences; $S$. sp. ZUR-4 (five specimens) and $S$. sp. ZUR-5 (one specimen) somewhat resemble $S$. leptopus (Kieffer) but differ in coloration and genitalic structures; $S$. sp. ZUR-6 (two specimens) is entirely pale like $S$. palliaculeatus Borkent, but has a stouter superior volsella; S. sp. ZUR-7 (two specimens) has an dark thorax like $S$. varius, but has numerous darkened abdominal tergites; and $S$. sp. ZUR-8 (two specimens) is unusual in having a globose/semi-pediform superior volsella.

Tanytarsus - Tanytarsus was by far the most common tanytarsine collected, with 140 specimens representing nine species. The majority did not fit descriptions of any known species, except $T$. cf. capaira (two specimens) resembles $T$. capaira described by Trivinho-Strixino \& Strixino
(2007) from Brazil, but appears a bit different; $T$. sp. ZUR-8 (one specimen) is also similar to $T$. cf. caipira but is much smaller. Tanytarsus sp. ZUR5 (16 specimens) is similar to T. cotopaxi Giłka \& Zakrzewska, described from Ecuador (Giłka \& Zakrzewska 2013). The majority of specimens were $T$. sp. ZUR-1 (47 specimens), including an intersex specimen; 23 specimens of $T$. sp. ZUR-2; 34 specimens of $T$. sp. ZUR-3; 14 specimens of $T$. sp. ZUR-6; and one specimen of $T$. sp. ZUR-7.

Xestochironomus - Four species were collected, one undescribed. I examined the holotype of $X$. ankylis, described from Guatemala by Sublette \& Sasa (1994); X. gilvus and X. latilobus were described from Venezuela by Borkent. Xestochironomus sp. ZUR-1, represented by seven specimens, will key to couplet 6 in Borkent (1984) but is neither X. subletti Borkent nor X. gilvus Borkent; it differs in having a very long, thin, anal point and almost straight superior volsellae.

CHIRCHIR -1 - This taxon is represented by one damaged specimen, missing its antennae and all tarsomeres. The wings are bare, the squama is fringed and the antepronotal lobes do not appear to meet medially. The gonostylus has an apical row of medially directed setae, all of which are broken off. The specimen also lacks a subapical seta on the superior volsella but has a subapical pit/sensillum, from which I can observe no indication of a broken or lost seta. This taxon may represent a new genus or be an aberrant Stenochironomus with separated tibial spurs (these spurs are fused in Stenochironomus); the specimen lacks the posteromedial patch of short setae on the gonostylus found on Xestochironomus. More, undamaged, material is needed.

\section{Discussion}

The Zurquí study has produced an impressive list of chironomid taxa, the majority of which $(72 \%)$ are undescribed. Noticeable in their absence were some common and widespread taxa such as $A b$ labesmyia, Chironomus, Coelotanypus, Goeldichironomus, Oukuriella and Tanypus. This is no doubt due to a dearth of suitable habitats, as many of those genera are more common in ponds and lakes, especially those with a bit of eutrophication; no such water bodies were present at Zurquí.

Many of the taxa collected are considered terrestrial, semi-terrestrial or phytotelmatic; most of these belong with the subfamily Orthocladiinae: Antillocladius, Bryophaenocladius, Compterosmittia, Lipurometriocnemus, Mesosmittia, Paraphaenocladius, Pseudosmittia and probably Diplosmittia; at least one Polypedilum, P. panacu, is phytotelmatic. 
It is unfortunate that the project's protocol did not include collecting the immature stages of Chironomidae, but a lack of funding (only half the requested amount for the grant was provided) made the laborious process of collecting larvae and pupae, and rearing them to adulthood, not possible. The likelihood that many of the taxa were probably terrestrial or semi-terrestrial (in wet moss, etc.), entailing an even more time-consuming process than collecting the immature stages from water, compounded the problem. One taxon collected in this survey, a member of Parochlus araucanus group, might have been identifiable to species if the pupal exuviae had been collected because the only species-specific characters for this group are found in the pupae (Brundin 1966).

As is demonstrated in this paper, the Neotropical Chironomidae (actually, all Diptera in the Neotropics) remain poorly known - and their immature stages, often used in environmental assessments in the Holarctic, even more so. Although Coffman et al. (1993) reported 266 species of chironomids from 13 streams in northwestern Costa Rica, based solely on pupal exuviae, none of those taxa have been supplied with an available name. Chironomid taxonomy relies mostly on characters of the male, especially the male genitalia, for species delimitation. Thus, collecting the immature stages must include rearing (or otherwise associating those stages, as with pharate pupae) to adulthood in order to associate those stages with the generally more better known adults, the bearers of the species' names. Alternatively, the use of suitable molecular markers (e.g. DNA bar codes), as shown by Trivinho-Strixino \& Pepinelli (2015), may also help to associate life stages with available names.

While 137 species from a four-hectare area may seem impressive, it pales with the numbers from some of the other families from the ZADBI project. Chironomidae only placed eleventh on the list of total species collected. The Cecidomyiidae topped the list, with about 800 species found. A more complete analysis of these numbers, plus other aspects of diversity, biogeography, ecology, etc., will be presented in a series of multi-authored papers currently being written about the ZADBI project.

\section{Acknowledgements}

Many thanks go to Art Borkent (Research Associate, Royal British Columbia Museum and the American Museum of Natural History) and Brian Brown (Natural History Museum of Los Angeles County, Los Angeles, CA) for developing, organizing and supervising the ZADBI project. Several technicians (see Borkent \& Brown 2015) at INBio sorted material to family; Annia Picado selected specific specimens and prepared the slides. Robin E. Thompson, Curator of the Insect Collection at the University of Minnesota, St. Paul, MN, made important types and other specimens available from the Sublette Collection housed there. Broughton Caldwell reviewed an earlier draft and helped improve this paper - many thanks, MB! Art Borkent and Torbjørn Ekrem made many suggestions which are incorporated in this paper. Thanks also to Rick Jacobsen for discussions on Manoa, Pseudochironomus and Riethia, and to Luiz Pinho for discussions on Diplosmittia. My wife Linda helped immensely by utilizing her typing skills, far superior to mine, entering the majority of the identifications and other data into spreadsheets. Thanks also to the two anonymous reviewers whose comments improved the paper and indirectly led me to some papers I had missed.

This research was partially funded by US National Science Foundation grant DEB 1145890 to B. Brown and A. Borkent.

\section{References}

Andersen, T. 1996. New species of Diplosmittia Sæther, 1981 from Costa Rica (Chironomidae, Orthocladiinae). - Acta Zoologica Academiae Scientiarum Hungaricae 42: 127-132.

Andersen, T. \& Mendes, H.F. 2002. Neotropical and Mexican Mesosmittia Brundin, with the description of four new species (Insecta, Diptera, Chironomidae). - Spixiana 25: 141-155.

Andersen, T., Mendes, H.F. \& Pinho, L.C. 2008. Two new species of Stenochironomus Kieffer, 1919 from the Brazilian Atlantic rain forest (Diptera: Chironomidae). - Studia Dipterologica 14: 263-269.

Andersen, T., Pinho, L.C. \& Mendes, H.F. 2016. Two new species of Lipurometriocnemus Sæther from Brazil (Diptera: Chironomidae, Orthocladiinae). - Revista Biotemas 29: 37-45.

Andersen, T. \& Sæther, O.A. 1996. New species and records of Beardius Reiss et Sublette (Diptera: Chironomidae). - Annales de Limnologie 32: $33-44$.

Andersen, T., Sæther, O.A. \& Contreras-Ramos, A. 2011. New species and records of Nandeva Wiedenbrug, Reiss et Fittkau. - Zootaxa 3136: 45-60.

Borkent, A. 1984. The systematics and phylogeny of the Stenochironomus complex (Xestochironomus, Harrisius, and Stenochironomus) 
(Diptera: Chironomidae). - Memoirs of the Entomological Society of Canada 128: 1-269.

Borkent, A. \& Brown, B.V. 2015. How to inventory tropical flies (Diptera) - One of the megadiverse orders of insects. - Zootaxa 3949: 301-322.

Brown, B.V., Borkent, A., Cumming, J.M., Wood, D.M., Woodley, N.E. \& Zumbado, M.A. (eds.) 2009. Manual of Central American Diptera. Volume 1. NRC Research Press, Ottawa, Ontario, Canada. 714 pp.

Brown, B.V., Borkent, A., Cumming, J.M., Wood, D.M., Woodley, N.E. \& Zumbado, M.A. (eds.) 2010. Manual of Central American Diptera. Volume 2. NRC Research Press, Ottawa, Ontario, Canada. 728 pp.

Brundin, L. 1966. Transantarctic relationships and their significance, as evidenced by chironomid midges. With a monograph of the subfamilies Podonominae and Aphroteniinae and the austral Heptagyiae. - Kungliga Svenska Vetenskapsakemiens Handlingar 11: 1-472.

Coffman, W.P., de la Rosa, C.L., Cummins, K.W. \& Wilzbach, M.A. 1993 [1992]. Species richness in some Neotropical (Costa Rica) and Afrotropical (West Africa) lotic communities of Chironomidae (Diptera). - Netherlands Journal of Aquatic Ecology 26: 229-237.

Cranston, P.S., Martin, J., Mulder, M. \& Spies, M. 2016. Clarification of Einfeldia Kieffer, 1922 (Diptera: Chironomidae) with E. australiensis (Freeman, 1961), comb. n. based on immature stages. - Zootaxa 4158: 491-506.

Cranston, P.S. \& Oliver, D.R. 1988. Additions and corrections to the Nearctic Orthocladiinae (Diptera: Chironomidae). - Canadian Entomologist 120: 425-462.

Dantas, G.P.S., Hamada, N. \& Mendes, H.F. 2016. Contribution to the knowledge of Stenochironomus Kieffer (Diptera, Chironomidae) from Brazil: seven new species and descriptions of females and immatures of some previously known species. - Zootaxa 4117: 1-47.

Donato, M. 2011. A new species of Bryophaenocladius (Diptera: Chironomidae) from Argentina. - Revista de la Sociedad Entomológica Argentina 70: 207-212.

Donato, M., Siri, A \& Mauad, M. 2012. Description of a new species of the genus Onconeura Andersen et Sæther (Diptera: Chironomidae) from Argentina with a cladistic analysis of the genus. - Zootaxa 3580: 43-55.

Ekrem, T. 2007. A taxonomic revision of the genus Stempellinella (Diptera: Chironomidae). Journal of Natural History 41: 1367-1465.

Epler, J.H. 1986. A novel new Neotropical Nanocladius (Diptera: Chironomidae), symphoretic on Traverella (Ephemeroptera: Leptophlebiidae). - The Florida Entomologist 69: 319-3327.

Epler. J.H. 1988. Biosystematics of the genus Dicrotendipes Kieffer, 1913 (Diptera: Chironomidae: Chironominae) of the World. - Memoirs of the American Entomological Society $36: 1-214$.

Epler, J.H. 2001. Identification Manual for the larval Chironomidae (Diptera) of North and South Carolina. A guide to the taxonomy of the midges of the southeastern United States, including Florida. Special Publication SJ2001SP13.- North Carolina Department of Environment and Natural Resources, Raleigh, NC, and St. Johns River Water Management District, Palatka, FL. 526 pp.

Epler, J.H. 2010. Phytotelmatocladius, a new genus from bromeliads in Florida and Brazil (Diptera: Chironomidae: Orthocladiinae). In Ferrington, L.C., Jr. (ed.) Proceedings of the $X V$ International Symposium on Chironomidae. Chironomidae Research Group, University of Minnesota, St. Paul, MN. pp. 285-293

Epler, J.H., Ekrem, T. \& Cranston, P.S. 2013. 10. The larvae of Chironominae of the Holarctic Region - Keys and diagnoses. In Andersen, T., Cranston, P. S. \& Epler, J. H. (Sci. eds): The larvae of Chironomidae (Diptera) of the Holarctic Region - Keys and diagnoses. Insect Systematics \& Evolution, Supplement 66: 1-571. pp. 387-556.

Erwin, T.L. 1982. Tropical forests: their richness in Coleoptera and other arthropod species. The Coleopterists Bulletin 36: 74-75.

Ferrington, L.C., Jr. \& Sæther, O.A. 2011. A revision of the genera Pseudosmittia Edwards, 1932, Allocladius Kieffer, 1913, and Hydrosmittia gen. n. (Diptera: Chironomidae, Orthocladiinae). - Zootaxa 2849: 1-314.

Giłka, W. \& Zakrzewska, M. 2013. A contribution to the systematics of Neotropical Tanytarsus van der Wulp: first descriptions from Ecuador (Diptera: Chironomidae: Tanytarsini). -Zootaxa 3619: 453-459.

Grodhaus, G. 1987. Endochironomus Kieffer, 
Tribelos Townes, Synendotendipes, n. gen., and Endotribelos, n. gen. (Diptera: Chironomidae) of the Nearctic Region. - Journal of the Kansas Entomological Society 60: 167-247.

Jacobsen, R.E. \& Perry, S.A. 2002. A new species of Manoa (Diptera: Chironomidae) from Everglades National Park. - Journal of the North American Benthological Society 21: 314-325.

Kyerematen, R.A.K. \& Andersen, T. 2002. Rheotanytarsus Thienemann et Bause (Diptera: Chironomidae) from Central America and Mexico. - Studies on Neotropical Fauna and Environment 37: 3-51.

Kyerematen, R.A.K., Saether, O.A. \& Andersen, T. 2000. A review of the Rheotanytarsus pellucidus group (Diptera: Chironomidae). In Hoffrichter, O. (ed.). Late $20^{\text {th }}$ Century Research on Chironomidae: An Anthology From the $13^{\text {th }}$ International Symposium on Chironomidae. Aachen, Shaker Verlag. pp. 147-170.

Mendes, H.F. \& Andersen, T. 2008. A review of Antillocladius Saether and Litocladius Mendes, Andersen et Saether, with the description of two new Neotropical genera (Diptera, Chironomidae, Orthocladiinae). - Zootaxa 1887: 1-75.

Mendes, H.F. \& Andersen, T. 2009. Neotropical Nilothauma Kieffer, 1921, with the description of thirteen new species (Diptera: Chironomidae). - Zootaxa 2063: 1-45.

Mendes, H.H. \& Andersen, T. 2013. Jururumberus, a new genus of Orthocladiinae (Diptera: Chironomidae) from Brazil. - Biota Neotropica 13: 71-76.

Mendes, H.F., Andersen, T. \& Hagenlund, L.K. 2011. New species and records of Antillocladius Saether and Litocladius Mendes, Andersen et Saether from Brazil and Costa Rica (Chironomidae: Orthocladiinae). - Zootaxa 2915: $39-51$.

Mendes, H.F., Andersen, T. \& Jocqué, M. 2011. A new species of Polypedilum Kieffer from bromeliads in Parque Nacional Cusuco, Honduras (Chironomidae: Chironominae). - Zootaxa 3062: 46-54.

Mendes, H.F, Andersen, T. \& Sæther, O.A. 2004. A review of Antillocladius Sæther, 1981; Compterosmittia Sæther, 1981 and Litocladius new genus (Chironomidae, Orthocladiinae). Zootaxa 594: 1-82.

Neubern, C.S.O., Trivinho-Strixino, S. \& Silva,
F.L. 2011. Riethia manauara n. sp., an Amazonian chironomid (Diptera: Chironomidae) from Brazil. - Neotropical Entomology 40: 595-599.

Pinho, L.C., Mendes, H.F. \& Andersen, T. 2009. A review of Diplosmittia Sæther, with the description of four new Neotropical species (Diptera: Chironomidae). - Studies on Neotropical Fauna and Environment 44: 163-182.

Pinho, L.C., Mendes, H.F. \& Andersen, T. 2013. Revision of Beardius Reiss et Sublette, 1985 (Diptera: Chironomidae), with the description of twenty new species. - Zootaxa 3742: 1-78.

Reis, E.D.A., Serpa-Filho, A. \& Ferreira-Keppler, R.L. 2013. Two new species and records of Stenochironomus Kieffer from Brazilian Amazon region, with description of immature stages (Diptera: Chironomidae). - Zootaxa 3710: 449-466.

Roback, S.S. 1982a. The Tanypodinae (Diptera: Chironomidae) of Australia II. - Proceedings of the Academy of Natural Sciences of Philadelphia 134: 80-112.

Roback, S.S. 1982b. Some new Procladius (Chironomidae: Tanypodinae) species from Colombia. - Proceedings of the Academy of Natural Sciences of Philadelphia 134: 122-126.

Roque, F.O. \& Trivinho-Strixino, S. 2008. Four new species of Endotribelos Grodhaus, a common fallen fruit-dwelling chironomid genus in Brazilian streams (Diptera: Chironomidae: Chironominae). - Studies on Neotropical Fauna and Environment 43: 191-207.

Sæther, O.A. 1969. Some Nearctic Podonominae, Diamesinae, and Orthocladiinae (Diptera: Chironomidae). - Fisheries Research Board of Canada Bulletin 170: 1-154.

Sæther, O.A. 1981. Orthocladiinae Diptera: Chironomidae) from the British West Indies with descriptions of Antillocladius n. gen., Lipurometriocnemus n. gen., Compterosmittia n. gen., and Diplosmittia n. gen. - Entomologica scandinavica Supplement 16: 1-46.

Sæther, O.A. 1982. Orthocladiinae (Diptera: Chironomidae) from SE U.S.A., with descriptions of Plhudsonia, Unniella and Platysmittia n. genera and Atelopodella n. subgen. -Entomologica Scandinavica 13: 465-510.

Sæther, O.A. 1985. The imagines of Mesosmittia Brundin, 1956, with description of seven new species (Diptera: Chironomidae). - Spixiana 
Supplement 11: 37-54.

Sæther, O.A. \&. Cranston, P.S. 2012. New World Stictocladius Edwards (Diptera: Chironomidae). - Neotropical Entomology 41: 124-149.

Sæther, O.A. \& Roque, F.O. 2004. New Neotropical species of Nandeva (Diptera: Chironomidae), with a phylogeny of the Tanytarsini. - Tijdschrift voor Entomologie 147: 63-80.

Sæther, O.A. \& Sublette, J.E. 1983. A review of the genera Doithrix n. gen., Georthocladius Strenzke, Parachaetocladius Wülker and Pseudorthocladius Goetghebuer (Diptera: Chironomidae, Orthocladiinae). - Entomologica scandinavica Supplement: 1-100.

Sæther, O.A. \& Wang. X. 1995. Revision of the genus Paraphaenocladius Thienemann, 1924 of the world (Diptera: Chironomidae, Orthocladiinae). - Entomologica scandinavica Supplement 48: 1-69.

Siri, A. \& Donato, M. 2014. Monopelopia caraguata (Chironomidae: Tanypodinae: Pentaneurini) and Phytotelmatocladius delarosai (Chironomidae: Orthocladiinae): two phytotelmatous chironomids distributed from Florida to Argentina. - Florida Entomologist 97: 12261231

Spies, M., Andersen, T., Epler, J.H. \& Watson, C.N., Jr. 2009. Chironomidae (non-biting midges). In Brown, B.V. et al. (eds.) Manual of Central American Diptera: Volume 1. NRC Research Press, Ottawa, Ontario, Canada. pp. 437-480

Spies, M., Fittkau, E.J. \& Reiss, F. 1994. The adult males of Parachironomus Lenz, 1921, from the Neotropical faunal region (Insecta, Diptera, Chironomidae). - Spixiana Supplement 20: 61-98.

Spies, M. \& Reiss, F. 1996. Catalog and bibliography of Neotropical and Mexican Chironomidae. - Spixiana Supplement 22: 61-119.

Sublette, J.E. 1967. Type specimens of Chironomidae (Diptera) in the Cornell University Collection. - Journal of the Kansas Entomological Society 40: 477-564.

Sublette, J.E. \& Sasa, M. 1994. Chironomidae collected in Onchocerciasis endemic areas of Guatemala. - Spixiana Supplement 20: 1-60.

Trivinho-Strixino, S. 2012. A systematic review of Neotropical Caladomyia Säwedal (Diptera: Chironomidae). Zootaxa 3495: 1-41.
Trivinho-Strixino, S. \& Pepinelli, M. 2015. A systematic study on Endotribelos Grodhaus (Diptera: Chironomidae) from Brazil including DNA barcoding to link males and females. Zootaxa 3936: 1-41.

Trivinho-Strixino, S. \& Strixino, G. 2007. A new Neotropical species of Tanytarsus van der Wulp, 1874 (Diptera: Chironomidae), with an unusual anal process. - Zootaxa 1654: 61-67.

Trivinho-Strixino, S., Roque, F.O. \& Cranston, P.S. 2009. Redescription of Riethia truncatocaudata (Edwards, 1931) (Diptera: Chironomidae), with description of female, pupa and larva and generic diagnosis for Riethia. - Aquatic Insects 31: 247-259.

Townes, H.K. 1945. The Nearctic species of Tendipedini (Diptera, Tendipedidae (= Chironomidae)). - The American Midland Naturalist 34: $1-206$.

Tuxen, S.L. (ed.) 1970. Taxonomist's Glossary of Genitalia in Insects. Second edition. Munksgaard, Copenhagen. 840 pp.

Wang, X, Andersen, T. \& Sæther, O.A. 2006. Neotropical Bryophaenocladius Thienemann, 1934 (Diptera: Chironomidae). - Studies on Neotropical Fauna and Environment 41: 19-32.

Watson, C.N., Jr. \& Heyn, M.W. 1993. A preliminary survey of the Chironomidae (Diptera) of Costa Rica, with emphasis on the lotic fauna. - Netherlands Journal of Aquatic Ecology 26: 257-262. (1992)

Wiedenbrug, S. \& Andersen, T. 2002. New species of Parakiefferiella Thienemann, 1936 from South America (Chironomidae, Orthocladiinae). - Studies on Neotropical Fauna and Environment 37: 119-132.

Wiedenbrug, S., Lamas, C.E. \& Trivinho-Strixino, S. 2012. A review of the genus Corynoneura Winnertz (Diptera: Chironomidae) from the Neotropical region. - Zootaxa 3574: 1-61.

Wiedenbrug, S., Mendes, H.F. \& Pepinelli, M. 2009. Review of the genus Onconeura Andersen et Sæther (Diptera: Chironomidae), with the description of four new species from Brazil. Zootaxa 2265: 1-26.

Wiedenbrug, S. \& Silva, F.L. 2013. New species of Nanocladius Kieffer, 1913 (Diptera: Chironomidae: Orthocladiinae) from Neotropical region. - Annales de Limnologie - International Journal of Limnology 49: 255-264. 
Wiedenbrug, S. \& Silva, F.L. 2016. Diplosmittia caribensis, a new Orthocladiinae (Diptera: Chironomidae) from the Dominican Republic. - Zootaxa 4103: 71-74.

\section{APPENDIX 1}

List of Chironomidae collected at Zurquí de Moravia, Costa Rica, 2012-2013

PODONOMINAE

Parochlus araucanus Brundin, 1966, group sp. ZUR-1

\section{TANYPODINAE}

Procladius (P.) sp. ZUR-1

Thienemannimyia (T.) sp. ZUR-1

Zavrelimyia (Paramerina) fasciata (Sublette

\& Sasa, 1994)

\section{ORTHOCLADIINAE}

Antillocladius antecalvus Sæther, 1981

Antillocladius arcuatus Sæther, 1982

Antillocladius pluspilalus Sæther, 1981

Bryophaenocladius cf. psilacrus Sæther, 1982

Bryophaenocladius sp. ZUR-1

Bryophaenocladius sp. ZUR-2

Bryophaenocladius sp. ZUR-3

Bryophaenocladius sp. ZUR-4

Compterosmittia nerius (Curran, 1930)

Compterosmittia sp. ZUR-1

Compterosmittia sp. ZUR-2

Corynoneura ferelobata Sublette \& Sasa, 1994

Corynoneura guanacaste Wiedenbrug, Lamas \& Trivinho-Strixino, 2012

Corynoneura sp. ZUR-1

Corynoneura sp. ZUR-2

Cricotopus sp. ZUR-1

Cricotopus sp. ZUR-2

Cricotopus sp. ZUR-3

Cricotopus sp. ZUR-4
Cricotopus sp. ZUR-5

Cricotopus sp. ZUR-6

Cricotopus sp. ZUR-7

Cricotopus sp. ZUR-8

Diplosmittia forficata Andersen, 1997

Diplosmittia sp. ZUR-1

Diplosmittia sp. ZUR-2

Eukiefferiella sp. ZUR-1

Eukiefferiella sp. ZUR-2

Eukiefferiella sp. ZUR-3

Gravatamberus guatemaltecus Mendes \& Andersen, 2008

Irisobrillia longicosta Oliver, 1985

Krenosmittia sp. ZUR-1

Limnophyes guatemalensis Sublette \& Sasa, 1994

Limnophyes mariae Sublette \& Sasa, 1994

Lipurometriocnemus glabalus Sæther, 1981

Lipurometriocnemus sp. ZUR-1

Lipurometriocnemus sp. ZUR-2

Lipurometriocnemus sp. ZUR-3

Litocladius chavarriai Mendes, Andersen \& Hagenlund, 2011

Lopescladius (Cordiella) sp. ZUR-1

Lopescladius (Cordiella) sp. ZUR-2

Mesosmittia patrihortae Sæther, 1986

Mesosmittia sp. ZUR-1

Metriocnemus costatus Sublette \& Sasa, 1994

Metriocnemus sp. ZUR-1

Metriocnemus sp. ZUR-3

Nanocladius sp. ZUR-1

Onconeura sp. ZUR-1 
Parakiefferiella sp. ZUR-1

Parametriocnemus sp. ZUR-1

Parametriocnemus sp. ZUR-2

Parametriocnemus sp. ZUR-3

Parametriocnemus sp. ZUR-4

Paraphaenocladius exagitans longipes Sæther \& Wang, 1995

Pseudorthocladius sp. ZUR-1

Pseudosmittia forcipata (Goetghebuer, 1921)

Pseudosmittia windwardensis (Sæther, 1981)

Pseudosmittia sp. ZUR-1

Stictocladius sp. ZUR-1

Synorthocladius sp. ZUR-1

CHIRORTH-1 sp. ZUR-1

CHIRORTH-2 sp. ZUR-1

CHIRORTH-3 sp. ZUR-1

CHIRORTH-4 sp. ZUR-1

CHIRORTH-4 sp. ZUR-2

CHIRORTH-5 sp. ZUR-1

CHIRORTH-6 sp. ZUR-1

CHIRORTH-7 sp. ZUR-1

CHIRORTH-8 sp. ZUR-1

CHIRORTH-9 sp. ZUR-1

CHIRORTH-10 sp. ZUR-1

CHIRORTH-11 sp. ZUR-1

CHIRORTH-12 sp. ZUR-1

CHIRORTH-13 sp. ZUR-1

CHIRORTH-14 sp. ZUR-1

CHIRORTH-15 sp. ZUR-1

CHIRORTH-16 sp. ZUR-1

\section{CHIRONOMINAE}

Beardius triangulatus Andersen \& Sæther, 1996

Beardius sp. ZUR-1

Caladomyia sp. ZUR-1

Caladomyia sp. ZUR-2

Cryptochironomus sp. ZUR-1

Dicrotendipes sp. ZUR-1
Einfeldia sp. ZUR-1

Endotribelos albatum Sublette \& Sasa, 1994

Endotribelos grodhausi Sublette \& Sasa, 1994

Endotribelos sp. ZUR-1

Nandeva latiloba Sæther \& Roque, 2004

Nilothauma sp. ZUR-1

Nilothauma sp. ZUR-2

Parachironomus sp. ZUR-1

Phaenopsectra sp. ZUR-1

Polypedilum (Pentapedilum) sp. ZUR-1

Polypedilum (Polypedilum) panacu Mendes, Andersen \& Jocqué, 2011

Polypedilum (Polypedilum) sp. ZUR-1

Polypedilum (Polypedilum) sp. ZUR-2

Polypedilum (Polypedilum) sp. ZUR-3

Polypedilum (Tripodura) apicatum Townes, 1945

Polypedilum (Tripodura) luteopedis Sublette \& Sasa, 1994

Polypedilum (Tripodura) obelos Sublette \& Sasa, 1994

Polypedilum (Tripodura) sp. ZUR-2

Polypedilum (Uresipedilum) sp. ZUR-1

Rheotanytarsus $c f$. contrerasi Andersen \& Sæther, 2000

Rheotanytarsus cf. guanacastensis Kyerematen \& Andersen, 2002

Rheotanytarsus scutulatus Kyerematen \& Andersen, 2002

Rheotanytarsus subtilis Kyerematen \& Andersen, 2002

Rheotanytarsus sp. ZUR-1

Riethia sp. ZUR-1

Stempellinella sp. ZUR-1

Stenochironomus nudipupa Borkent, 1984

Stenochironomus cf. varius Borkent, 1984

Stenochironomus sp. ZUR-1

Stenochironomus sp. ZUR-2

Stenochironomus sp. ZUR-3

Stenochironomus sp. ZUR-4

Stenochironomus sp. ZUR-5 
Stenochironomus sp. ZUR-6

Stenochironomus sp. ZUR-7

Stenochironomus sp. ZUR-8

Tanytarsus cf. caipira Trivinho-Strixino \& Strixino, 2007

Tanytarsus sp. ZUR-1

Tanytarsus sp. ZUR-2

Tanytarsus sp. ZUR-3

Tanytarsus sp. ZUR-4
Tanytarsus sp. ZUR-5

Tanytarsus sp. ZUR-6

Tanytarsus sp. ZUR-7

Tanytarsus sp. ZUR-8

Xestochironomus ankylis Sublette \& Sasa, 1994

Xestochironomus gilvus Borkent, 1984

Xestochironomus latilobus Borkent, 1984

Xestochironomus sp. ZUR-1

CHIRCHIR-1 sp. ZUR-1

Article submitted 19. February 2017, accepted by Torbjørn Ekrem 7. April 2017, published 21. April 2017. 